\title{
An Indo-Pacific damselfish (Neopomacentrus cyanomos) in the Gulf of Mexico: origin and mode of introduction
}

\author{
D Ross Robertson ${ }^{\text {Corresp., }}{ }^{1}$, Omar Dominguez-Dominguez ${ }^{2,3}$, Benjamin Victor ${ }^{4}$, Nuno Simoes ${ }^{5,6,7}$ \\ 1 Naos Marine Laboratory, Smithsonian Tropical Research Institute, Balboa, Republic of Panama \\ 2 Laboratorio de Biologia Acuatica, Facultad de Biologia, Universidad Michoacana de San Nicolás de Hidalgo, Morelia, Michoacan, Mexico \\ 3 Laboratorio Nacional de Análisis y Síntesis Ecológica para la Conservación de Recursos Genéticos de México, Escuela Nacional de Estudios Superiores, \\ Unidad Morelia, Universidad Nacional Autónoma de México, Morelia, Michoacán, Mexico \\ 4 Guy Harvey Research Institute, Nova Southeastern University, Ft Lauderdale, Florida, United States \\ 5 Unidad Multidisciplinaria en Docencia e Investigacion de Sisal, Facultad de Ciencias, UNAM, Sisal, Yucatan, Mexico \\ 6 Laboratorio Nacional de Resiliencia Costera, Unidad Académica de Yucatán, Universidad Nacional Autónoma de México, Sisal, Yucatán, Mexico \\ 7 Harte Institute for Gulf of Mexico Studies, Texas A\&M University - Corpus Christi, Corpus Christi, Texas, United States
}

Corresponding Author: D Ross Robertson

Email address: drr@stri.org

The Indo-West Pacific (IWP) coral-reef damselfish Neopomacentrus cyanomos is well established across the south-west Gulf of Mexico (SwGoMx). Comparisons of mtDNA sequences of the SwGoMx population with those from conspecifics from 16 sites scattered across its native geographic range show that the SwGoMx population is derived from two of four native lineages: one from the north-west Pacific Ocean, the other from the northern Indian Ocean. Three hypotheses address how this species was introduced to the SwGoMX: (1) aquarium release; (2) borne by cargo-ship; and (3) carried by offshore petroleum platform (petro-platform). The first is unlikely because this species rarely features in the aquarium trade, and "N. cyanomos" traded to the USA from the sole IWP source we are aware of are a misidentified congener, $N$. taeniurus. The second hypothesis is unlikely because shipping has not been associated with the introduction of alien damselfishes, there is little international shipping between the IWP and the SwGoMx, and voyages between those areas would be lengthy and along environmentally unfavorable routes. Various lines of evidence support the third hypothesis: (i) bio-fouled petro-platforms represent artificial reefs that can sustain large and diverse populations of tropical reeffishes, including N. cyanomos in the SwGoMx; (ii) relocation of such platforms has been implicated in trans-oceanic introductions leading to establishment of non-native populations of such fishes; and (iii) genetic characteristics of the SwGoMx population indicate that it was established by a large and diverse group of founders drawn from the IWP regions where many petro-platforms currently in the SwGoMx and other Atlantic offshore oilfields originated. 
1 An Indo-Pacific damselfish (Neopomacentrus cyanomos) in the Gulf of Mexico:

2 origin and mode of introduction.

3 D Ross Robertson ${ }^{1}$, Omar Dominguez-Dominguez ${ }^{2,3}$, Benjamin Victor ${ }^{4}$, Nuno

4 Simoes $^{5-7}$

5 1. Smithsonian Tropical Research Institute, Balboa, Republic of Panamá

7 2. Laboratorio de Biología Acuática, Facultad de Biología, Universidad Michoacana de

8 San Nicolás de Hidalgo, Francisco J. Mujica S/N, Morelia Michoacán, 58030,

$9 \quad$ México.

3. Laboratorio Nacional de Análisis y Síntesis Ecológica para la Conservación de Recursos Genéticos de México, Escuela Nacional de Estudios Superiores, Unidad Morelia, Universidad Nacional Autónoma de México, Apartado Postal 27-3 (Xangari), 58089, Morelia, Michoacán, México.

4. Guy Harvey Research Institute, Nova Southeastern University, Ft Lauderdale, Florida 33314 , USA

5. UMDI-Sisal, Facultad de Ciencias, Universidad Nacional Autónoma de México, Sisal 97355, Yucatán, México

6. Laboratorio Nacional de Resiliencia Costera, Unidad Académica de Yucatán, Universidad Nacional Autónoma de México, Sisal, 97355, Yucatán, México 
7. International Chair for Coastal and Marine Studies in Mexico, Harte Research Institute for Gulf of Mexico Studies, Texas A\&M University-Corpus Christi, 6300 Ocean Drive, Unit 5869 Corpus Christi, Texas 78412

Corresponding Author: D Ross Robertson, drr@stri.org

\section{ABSTRACT}

The Indo-West Pacific (IWP) coral-reef damselfish Neopomacentrus cyanomos is well established across the south-west Gulf of Mexico (SwGoMx). Comparisons of mtDNA sequences of the SwGoMx population with those from conspecifics from 16 sites scattered across its native geographic range show that the SwGoMx population is derived from two of four native lineages: one from the north-west Pacific Ocean, the other from the northern Indian Ocean. Three hypotheses address how this species was introduced to the SwGoMX: (1) aquarium release; (2) borne by cargo-ship; and (3) carried by offshore petroleum platform (petro-platform). The first is unlikely because this species rarely features in the aquarium trade, and " $N$. cyanomos" traded to the USA from the sole IWP source we are aware of are a misidentified congener, $N$. taeniurus. The second hypothesis is unlikely because shipping has not been associated with the introduction of alien damselfishes, there is little international shipping between the IWP and the SwGoMx, and voyages between those areas would be lengthy and along environmentally unfavorable routes. Various lines of evidence support the third hypothesis: (i) bio-fouled petro-platforms represent artificial reefs that can sustain large and diverse populations of tropical reef-fishes, including N. cyanomos in the SwGoMx; 
48 (ii) relocation of such platforms has been implicated in trans-oceanic introductions

49 leading to establishment of non-native populations of such fishes; and (iii) genetic characteristics of the SwGoMx population indicate that it was established by a large and

51 diverse group of founders drawn from the IWP regions where many petro-platforms currently in the SwGoMx and other Atlantic offshore oilfields originated.

53

\section{INTRODUCTION}

The damselfish Neopomacentrus cyanomos (Bleeker,1856), which is native to coral reefs of the tropical Indo-West Pacific (IWP) (Allen, 1991), was first recorded in the south-west Gulf of Mexico (SwGoMx) in mid-2013 (González-Gándara \& CruzFrancisco, 2014). However, by then it was common on both coastal and offshore reefs dispersed across at least $350 \mathrm{~km}$ of that area (Robertson et al., $2016 \mathrm{a}$ ). Since then, this species has been found across most of the SwGoMx, and, most recently, on petroplatforms, artificial- and natural reefs in both the north-west and north-east Gulf of Mexico (Schofield, 2017). After the lionfish (Pterois volitans), which arguably represents a single species in the west Atlantic (cf. Wilcox et al., 2017), N. cyanomos is only the second species of IWP coral-reef fish to have established a substantial population across a large area of the tropical Greater Caribbean. This paper deals with two questions: (i) from where in its native range did the SwGoMx population of $N$. cyanomos originate, and (ii) by what means were the fish that established that population transported to the Gulf of Mexico.

To address these two questions we compared DNA sequences of the mitochondrial DNA cytochrome c oxidase I gene (CO1 sequences) to assess 
relationships among three groups of fish: (i) aquarium-trade fish purchased in the USA that were supposedly "N. cyanomos" shipped from the Philippines; (ii) a large group of individuals of $N$. cyanomos we collected from two reefs in the SwGoMx; and (iii) samples of $N$. cyanomos collected at 16 sites scattered across most of its native range in the IWP

We used these genetic data to assess the following predictions relating to three hypothesized modes by which tropical reef-fishes have been transported long distances to sites well outside their native ranges: (1) release of aquarium specimens (Semmens et al., 2004; Schofield et al., 2009); (2) carriage by cargo-ship, on the hull or in ballast water (González-Gándara \& Cruz-Francisco, 2014); and (3) carriage by marine platforms used for exploration and production of offshore oil and gas ("petro-platforms") (Robertson et al., $2016 \mathrm{~b}$ ). We predicted that if the $N$. cyanomos population in the SwGoMx was established by aquarium release, then individuals from the SwGoMx should match genetically to those supplied by the aquarium trade from the Philippines (apparently the sole source of fish labelled as this species for the US trade to the Americas during the early 2000 s, the only period for which published data are available; https://www.aquariumtradedata.org/, accessed July 15, 2017). Since it is likely that an aquarium release of an obscure species such as $N$. cyanomos, a minor component in the international fish trade, would involve a relatively small number of individuals, then the N. cyanomos population in the SwGoMx should have low genetic diversity and show evidence of having passed through a genetic bottleneck due to its expansion from a small number of founders (a founder effect). Similarly, if the introduction were from transport by cargo-ship, a method not conducive to transport of large numbers of 
93 individual fishes in a single event, we predicted a SwGoMx population with genetic

94 characteristics essentially the same as those for a population established by aquarium

95

release, i.e. low genetic diversity, with evidence of a founder effect (Bernardi et al., 2010; Seixas et. al., 2017). In contrast, we predicted that transfer by petro-platforms would produce a markedly different genetic profile in the GoMx population. These platforms can host substantial populations of a range of species of tropical reef-fishes (Hastings, Ogren \& Mabry, 1976; Ferreira, Goncalves \& Coutinho, 2006; Friedlander et al., 2015; and Pradella et al., 2014), and at least one small platform in the SwGoMx supports a high-density population of many tens of thousands of $N$. cyanomos (Simoes \& Robertson, 2016). Hence a platform being transported from the IWP potentially could carry a substantial number of individuals representing a cross section of the population(s) of $N$. cyanomos from the IWP site(s) where it had been constructed or stationed before arriving in the GoMx. A GoMx population that was genetically diverse and showed no signs of having passed through a genetic bottleneck due to small founder-population size would be consistent with such a mode of introduction. In addition, that GoMx population should be most closely related to an IWP population(s) in an area(s) that contain offshore oilfields and where petro-platforms were constructed or stationed before being moved to the SwGoMx.

\section{MATERIALS AND METHODS}

Research at Cayo Arcas in 2016 was permitted by the Mexican Navy (SEMAR DO: 112/162), which also provided logistical support for that activity. An ACUC permit from the Smithsonian Tropical Research Institute (no. 2017-1107-2020) approved methods used to collect specimens of Neopomacentrus cyanomos there. 
116 Study species and origin of DNA sequences

117 The native IWP range of $N$. cyanomos extends from the Red Sea and the

118 Persian Gulf to south-east Africa, and eastward to Japan, the Philippines, the Solomon

119 Islands and New Caledonia in the West-Pacific. (Allen, 1991;

120 https://www.gbif.org/species/2398535, accessed Sept. 20, 2017). The range of $N$.

121 cyanomos encompasses most of the range of the entire genus, which extends only

122 further southeast, to the south-central Pacific (Allen, 1991;

123 https://www.gbif.org/species/2398526, accessed Sept. 20, 2017). No members of the

124 genus occur naturally in the Atlantic Ocean (Allen, 1991), and none are yet known from

125 the Mediterranean Sea, either naturally (Allen, 1991) or as a result of introduction (Arndt

126 \& Schembri, 2015).

The DNA sequences of $N$. cyanomos that we analysed came from four sources:

(i) tissue samples of fish we collected in the Gulf of Mexico; (ii) tissue samples from fish collected at various sites in the IWP that we obtained from other researchers; (iii) sequences independently obtained by other researchers from different sites in the IWP and compiled by the Fish Barcode of Life Initiative (FISH-BOL; http://www.fishbol.org/); and (iv) tissue samples from putative aquarium-trade $N$. cyanomos.

The 128 sequences we analysed included 54 from documented $N$. cyanomos

134 (many identified by GR Allen), that had been collected by a variety of researchers, including contributors to the FISH-BOL database, at 16 sites (1-8 fish per site) scattered

136 across most of the native IWP range. These sequences were compared to sequences

137 of 65 individuals of $N$. cyanomos we collected from the non-native population in the 
138 SwGoMx on Campeche Bank, two from Madagascar reef in 2015 (Robertson et al.,

1392016 b) and 63 from Cayo Arcas reef in 2016. After collection using the anaesthetic

140 clove-oil those 65 fish were euthanized with an overdose of that oil, and a pectoral fin

141 from each was preserved in $95 \%$ ethanol for use as a tissue sample from which we

142 obtained DNA. In addition we analysed sequences from nine aquarium-trade fish we

143 purchased in the USA that were identified by the US wholesale dealers as " $N$.

144 cyanomos" from the Philippines (eight from a single group purchased in Los Angeles,

145 California, and one from New York, New York). Table S1 provides information on

146 sample sites, numbers of sequences and their Genbank Accession numbers, and

147 indicates how we obtained all DNA sequences used in this study, both those from Fish

148 we collected or tissue samples sent to us by third parties, and those from other

149 contributors to the FISH-BOL database.

150

151

152

153

154

155

156

157

158

159

160

\section{DNA sequencing}

DNA extractions were performed with the NucleoSpin96 (Machery-Nagel) kit according to manufacturer's specifications under automation with a Biomek NX liquidhandling station (Beckman-Coulter) equipped with a filtration manifold. PCR amplifications were performed on volumes of $12.5 \mu \mathrm{l}$ compose of $6.25 \mu \mathrm{l}$ of $10 \%$ trehalose, $2 \mu \mathrm{l}$ of ultra pure water, $1.25 \mu \mathrm{l}$ of $10 \times$ PCR buffer $(10 \mathrm{mM} \mathrm{KCl}, 10 \mathrm{mM}$ (NH4)2SO4, 20mM Tris-HCl (pH8.8), 2mM MgSO4, 0.1\% Triton X-100), $0.625 \mu \mathrm{l}$ of $\mathrm{MgCl} 2(50 \mathrm{mM}), 0.125 \mu \mathrm{l}$ of each primer $(0.01 \mathrm{mM}), 0.0625 \mu \mathrm{l}$ of each dNTP $(10 \mathrm{mM})$, $0.0625 \mu \mathrm{l}$ of Taq DNA polymerase (New England Biolabs), and $2 \mu \mathrm{l}$ of template DNA. The PCR conditions consisted of $94^{\circ} \mathrm{C}$ for two min., 35 cycles of $94^{\circ} \mathrm{C}$ for $30 \mathrm{sec} ., 52^{\circ} \mathrm{C}$ for $40 \mathrm{sec}$., and $72^{\circ} \mathrm{C}$ for one min., with a final extension at $72^{\circ} \mathrm{C}$ for $10 \mathrm{~min}$. Sequences 
161 from the native-range specimens (other than those available on FISH-BOL) were

162 obtained from The Biodiversity Institute of Ontario, University of Guelph, Canada, while

163 those from the SwGoMx were provided by Macrogen Inc., The Netherlands.

164 Phylogenetic analysis and haplotype network reconstruction

Nucleotide sequences were edited and manually aligned in Mega v.6.06 (Tamura

et al., 2013) and examined with a chromatogram. A final alignment of 594 base pairs

was used in the analyses. Maximum likelihood (ML) analysis was conducted with

RAxMLGUI v. 1.3.1 (Stamatakis, 2006; Silvestro \& Michalak, 2012), performing 10,000 bootstrap replicates, and using the evolutionary substitution model estimated with the GTR+G model, as obtained in jModelTest (Posada, 2008) according to AIC (Posada, 2008). The relative stability of clades was evaluated by 1,000 non-parametric bootstrap replicates. N. azysron and N. sororius (Genbank \# KP194962.1, and BOLD \#

PCOM166-10, respectively) were used as out-groups. The haplotype network was constructed using PopART (available at http://popart.otago.ac.nz/downloads.shtml) and applying the Median-Joining method (Bandelt, Forster \& Rohl, 2000).

\section{Historical demography}

To detect signatures of demographic changes in populations of each of the four native lineages and the two lineages of $N$. cyanomos found in the SwGoMx (those belonging to groups 1 and 4 in the haplotype network of Figs. $1 \& 2$ ), Tajima's D (Tajima, 1989), and Fu's Fs (Fu \& Li, 1993) neutrality tests were calculated, in DNAsp v5 (Librado and Rozas, 2009). Evidence of an expanding population of a lineage would be assumed if significant negative values of Tajima's D and Fu's F-statistics were obtained (Mousset et al., 2004). Additionally, a pairwise mismatch distribution was 
184 computed for each of those six populations in DNAsp v5 (Librado \& Rozas, 2009).

185 Populations that have been historically stable are predicted to have multimodal

186

187

188

189

190

191

192

193

mismatch distributions, whereas those that have undergone a recent expansion are predicted to be unimodal (Slatkin \& Hudson, 1991). To test if the observed mismatch distributions predicted a stable or an expanding population model, differences between observed and expected (multimodal) distributions were evaluated using the Harpending's raggedness index (Harpending et al., 1993) and the $\mathrm{R}_{2}$ statistic (Ramos-

Onsins \& Rozas, 2002). Diversity indices were calculated for each genetic group among both the native-range and SwGoMx populations, and for combined populations, using the program DNAsp v5 (Librado \& Rozas, 2009).

\section{RESULTS}

The haplotype network for the entire set of 128 sequences is presented in Fig. 1, and the locations from which individuals in the four major haplotype groups of $N$.

cyanomos identified in that figure were obtained are shown in Fig. 2. Genetic diversity parameters of these different haplotype groups are displayed in Table 1.

The aquarium-trade specimens supposedly from the Philippines are only distantly related to all $N$. cyanomos sequenced here, and were identified by us, both morphologically and genetically, as a different species, Neopomacentrus taeniurus (Bleeker, 1856), which is native to brackish non-reef environments and widely distributed in the IWP (Allen, 1991). The mtDNA lineage of those aquarium-trade fish is separated by $80-89$ mutation steps from all four haplotype groups of $N$. cyanomos, from both the native sites and the SwGoMx (Fig. 1). 
All native-range specimens of $N$. cyanomos belonged to four closely related

207 haplotype groups and all SwGoMx fish belonged to two of those haplotype groups

208 (groups $1 \& 4$; Fig 1.). The native-range specimens had a total of 23 haplotypes, 12 of

209 those from groups 1 and 4 (18 of 54 individuals; Fig. 1, Table 1). The 65 SwGoMx

210

sequences included 11 haplotypes, four of which were shared with native-range

211

specimens of groups 1 and 4 (Fig. 1, Table 1). Haplotype diversity and nucleotide

212

diversity were high within each of the four genetic groups from the native-range (Table

213

1). While haplotype diversity also was high in the SwGoMx populations of groups 1 and

4 , in each case the level was lower than in the native-range population of the same group (Table 1). Nucleotide diversity in each of groups 1 and 4 of the SwGoMx population was a little lower than in the native group of each case, but similar to nucleotide diversity in the other two groups (2 and 3 ) from the native population (Table 1).

The SwGoMx population comprised roughly equal numbers of individuals drawn from the two haplotype groups that are largely geographically separated in the native range, with group 1 restricted to the northern Indian Ocean and group 4 found in samples from Indonesia and Taiwan in the north-west Pacific Ocean (Fig. 2). The only exception to this pattern of geographic separation is one individual of group 4 that was collected at Gujarat, in India, at the same location as two individuals of group 1.

The results of the neutrality tests showed that Tajima's D and Fu's Fs values were not statistically significant for any of the four groups in the native range, or for either of groups 1 and 4 in the SwGoMx (Table 1). Each of those six groups showed a 
229 raggedness index and the $R_{2}$ statistic (Table 1 ). Thus none of those six groups showed

230 evidence of having passed through a bottleneck due to a founder effect.

\section{DISCUSSION}

The analysis of mtDNA sequences indicate that the SwGoMx population of $N$. cyanomos is unrelated to the aquarium-trade fish from the Philippines, which represent a different species, N. taeniurus. Most significantly, the SwGoMx population is derived from two distinct genetic lineages of $N$. cyanomos found in the native range, is genetically diverse, and neither of those GoMx lineages shows signs of having passed through a genetic bottleneck due to a founder effect. Lastly, the SwGoMx population is derived from a combination of a lineage found in the northern Indian Ocean and another from two widely separated locations in the northwest Pacific Ocean (Taiwan and Indonesia). These results permit an evaluation of alternative hypotheses on the origin and mode of introduction of this alien species into the Gulf of Mexico.

\section{Aquarium-Release Hypothesis:}

The aquarium-trade specimens sold as "N. cyanomos" proved to belong to a different species. As part of a separate phylogenetic study of the genus, one of us (B Victor) has obtained mtDNA CO1 sequences of specimens of all 15 nominal species of Neopomacentrus that were collected in the field and identified by an expert in damselfish taxonomy (GR Allen). The mtDNA sequences of the Philippines aquariumtrade specimens are nested within a cluster of barcodes of specimens identified as $N$. taeniurus that were obtained from multiple locations (sequences in Appendix I). In

250 addition, our morphological examinations confirmed this identification: Species of 
251 Neopomacentrus fall into two morphological groups, one (including N. cyanomos) with

252 the lower edge of the suborbital bone hidden under a covering of scales, and the other

253 (including N. taeniurus) in which the suborbital margin is exposed and not covered by

254 scales (Allen, 1991). Specimens from the SwGoMx we examined all have a hidden

255 suborbital margin, while the aquarium-trade specimens of " $N$. cyanomos" we examined

256 all have exposed suborbitals. $N$ taeniurus has a similar color pattern to, and can be

257 easily mistaken for $N$. cyanomos.

Aquarium-trade data presented by Rhyne et al. (2015) indicate that " $N$.

cyanomos", which is not brightly colored like many desirable aquarium species, is a very

small component of the aquarium trade in IWP reef-fishes to the USA (not sold in

261

sufficient numbers to be represented among the top 20 species of damselfishes), and

262

that the Philippines apparently is the sole native-range source for that trade to the USA.

263

Neopomacentrus cyanomos is known to occur in the Philippines, but whether or not any aquarium-trade imports from there actually are that species remains uncertain.

Furthermore, it is not clear which mitochondrial lineage(s) of $N$. cyanomos is present in

the Philippines, given the proximity of that archipelago to not only of the Group 4 lineage

267 (one of the SwGoMx lineages), but also the Group 2 lineage at Western Papua (Fig. 2).

Even if the Group 4 lineage of $N$. cyanomos that is present in the SwGoMx is exported

from the Philippines in the aquarium trade to the US, the northern Indian Ocean lineage

270

(Group 1) that forms a major part of the SwGoMx population would not be expected to

271 be part of the trade.

While keeping marine aquarium-fish is popular and widespread in countries like

273 the US, that is not the case in Mexico (N Simoes, personal observations), where 
274 attention to the international trade in marine aquarium fish is focused primarily on export

275 of native species (e.g. Lango-Reynoso et al., 2012). Any individuals of alien marine

276 fishes obtained by aquarists in Mexico likely would have been derived from US

277 wholesalers, the main global recipient in the aquarium trade. Personnel at a large public

278 aquarium at the city of Veracruz, in the SwGoMx, the only such installation in the

279 Mexican part of the Gulf of Mexico, have confirmed that $N$. cyamonos has never been

280 maintained in that facility (H. Pérez-España, pers. comm. Dec.14, 2017). Almost all

281 recorded aquarium-trade releases of exotic marine fish in or adjacent to the GoMx have

282 occurred in southern Florida, where at least 31 species (14 different families) of alien

283 reef-fishes have been recorded (Semmens et al., 2004; Schofield et al., 2009). N.

284 cyanomos would be expected to have established in southern Florida first if its GoMx

285 population was derived from aquarium release. It has not been discovered there

286 (Schofield, 2017; accessed Dec. 20, 2017), despite the fact that southeast Florida hosts

287 an abundance of divers, and is intensively monitored by the REEF organization

288 (www.reef.org) for sightings of exotic species. REEF was made aware of the presence

289 of $N$. cyanomos in the Gulf of Mexico by the publication of González-Gándara \& Cruz-

290 Francisco (2014), and members of that organization have been looking for this species

291 on south Florida reefs.

292

The genetic data do not support the aquarium-release hypothesis. Both SwGoMx

293 lineages of $N$. cyanomos are genetically diverse, and the results of both the neutrality

294 tests and mismatch distributions indicate a stable population that did not pass through a

295 genetic bottleneck due to a founder effect, and hence was not established by a few fish

296 released from an aquarium. 


\section{Cargo-ship carriage hypothesis:}

There are very few instances of long-distance introductions by alien

300

301

302

303

304

305

306

307

308

309

310

311

312

313

314

315

316

317

318

319

damselfishes. One of those evidently is due to a range expansion within the Pacific by a species that associates with flotsam (Abudefduf vaigiensis (Quoy \& Gaimard, 1825), Coleman et al., 2014). Another introduction (of another Abudefduf species that also associates with flotsam) from the Atlantic to the Mediterranean, has been attributed to ship-transport by Occhipinti-Ambrogi et al. (2011), without further detail or presentation of any justification (see Tsadok et al., 2015 for resolution of the identity of this species; and Pajuelo et al., 2016, below).

Ship-transport was proposed as the means of introduction of $N$. cyanomos into the SwGoMx by González-Gándara \& Cruz-Francisco (2014). Movements of cargoships in the normal course of business have been implicated in the long-distance transport of exotic marine fishes well beyond their native ranges, usually in ballast water (Wonham, Carlton \& Ruiz, 2000), but, potentially, also in sea-chests on the outside of the hulls of ships. Damselfishes are not included among the species thought to be introduced by ballast water (Wonham, Carlton \& Ruiz, 2000) and none were found on the hulls of cargo ships examined in Brazil by Ferriera, Goncalves \& Coutinho (2006). Sea chests are screened containers on the outside of the hulls that house the water intakes of a ship, inside which diminutive, crevice-dwelling reef-fishes such as gobies and blennies have been found (Wonham, Carlton \& Ruiz, 2000; Coutts \& Dunham 2007). However, N. cyanomos is not a crevice-living species and typically feeds on plankton in a flow of water $0.5-1 \mathrm{~m}$ above the substrate rather than maintaining contact 
320 with it. Whether a species with these characteristics is likely to be able to survive a long

321 voyage in a sea-chest with functioning water intakes, and do so in large enough

322 numbers to establish a genetically diverse population when it arrives in a different ocean

323 is far from certain.

A modern cargo-ship, which typically will not have a heavily fouled hull, travelling at $20-25$ knots (37-46 kph) on a voyage from the western Pacific (Hong Kong) to the SwGoMx via the Panama Canal would take $\sim 19-23$ days. A similar voyage would take 16-20 days from Northwest India via the Suez Canal (both calculated on http://seadistances.org, accessed Sept. 20 2017), not counting stoppages at any ports during the voyage. Survivorship in ballast water is time-dependent for many marine organisms (Muirhead et al., 2015) and, in addition to the lengthy duration of a transit by either route, the Pacific route would pose additional environmental barriers for transport of tropical reef-fish hitching a ride on the hull of a cargo-ship going to the Gulf of Mexico via that route. Most such traffic goes via California (Figure S1), which has a temperate climate with cold winter waters. However, average water temperatures near the major port of Long Beach, California, peak at $\sim 20^{\circ} \mathrm{C}$ for several months during summer, the same as average minimum winter temperatures at the latitudinal limits of the IWP range of $N$. cyanomos. In addition sea temperatures off California are elevated above the norm during El Niño events. Thus the sea temperature regime on the coast of California would reduce, but not eliminate, the possibility of successful carriage to Mexico.

Second, passing through the Panama Canal (see Figure S1) exposes any hullassociated organisms to the freshwater lake that constitutes most of that canal, and 
343 separated by the Isthmus of Panama (although a few euryhaline, non-reef fishes that

344 live in brackish environments have made the transit; reviewed in Cohen, 2006; and

345 Robertson \& Allen 2015; Robertson \& Van Tassell 2015).

In addition, due to the fact that the Panama Canal represents a major global

347 choke point for international shipping (see Figure S1), one would expect the first

348 occurrence of marine reef-fishes transported across the Pacific in this manner to be on

349 reefs adjacent to the Pacific end of the canal, where ships often stop before making a

350 canal transit. However, there are no records of such occurrences (review in Cohen

351 2006; Robertson \& Allen, 2015; Robertson \& Van Tassell, 2015), at either end of the 352 canal.

As with the aquarium-release hypothesis, the genetic data do not support this hypothesis, since both the SwGoMx lineages of $N$. cyanomos are genetically diverse, 355 and show no signs of having passed through a genetic bottleneck and hence was not established by a few founders, i.e. by a few fish transported in ballast water or on the hull of a cargo ship.

If $N$. cyanomos is capable of being carried far from its native range by cargo-ship in large enough numbers to establish a genetically diverse population, that would be much more likely to occur near major ports (e.g. Miami, Florida, or Panama, or somewhere in the Mediterranean), than in the southwest Gulf of Mexico. However, there are no indications that such has happened.

Petro-platform translocation hypothesis: 
365 fishes belonging to a broad variety of taxa, in the Gulf of Mexico (Hastings, Ogren \&

366 Mabry, 1976; Topolski \& Szedlmayer, 2004; Ajemian et al., 2015), Brazil (Ferreira,

367 Goncalves \& Coutinho, 2006), California (Claisse et al., 2014; Martin \& Lowe, 2010), the

368 Mediterranean (Consoli et al., 2013), west Africa (Friedlander et al., 2015), Australia

369 (Pradella et al., 2014), the Canary Islands (Pajuelo et al., 2016), and the Persian Gulf

370 (Torquato et al., 2017). In the SwGoMx, we have observed N. cyanomos living on two

371 such platforms, including in superabundance on a relatively lightly-fouled platform near

372 Cayo Arcas, in the southwest corner of Campeche Bank (up to $\sim 100$ individuals $\mathrm{m}^{-2}$;

373 Simoes \& Robertson, 2016). That platform is one of several hundred platforms in the

374 area of the greatest concentration of such structures in the SwGoMx

375 (https://portal.cnih.cnh.gob.mx/iicnih/?lng=en US, accessed Sept. 20, 2017).

Translocated petro-platforms have long been known to be vectors of long-

distance transport of sessile fouling organisms (Foster \& Willan, 1979; Bax et al., 2003;

Hopkins \& Forrest 2010; Wanless et al., 2010; Yeo et al., 2010; Mineur et al., 2014).

Recently, such movements have been implicated in the transoceanic transport of

western Atlantic reef-fishes to the Canary Islands, where a platform-servicing center has been established (Falcon et al., 2015; Pajuela et al., 2016), as well as to the Mediterranean (Dulcic \& Dragicevic, 2013; Pajuela et al., 2016). Some reef-fish species apparently carried to the Canary Islands by petro-platforms have established breeding populations there (Falcon et al., 2015; Pajuelo et al., 2016). Petro-platforms may help exotic reef-fishes establish off the coast of west Africa (Friedlander et al., 2014), and translocated platforms may have carried eastern Atlantic reef-fishes to Brazil, where some have recently become established (Pajuelo et al., 2016; Anderson et al., 2017). 
Relocated petro-platforms originating in the Indian Ocean are thought to have

389

390

391

392

393

394

395

396

397

398

399

400

401

402

403

404

405

406

407

408

409

410

transported alien fishes to the Mediterranean Sea (Galil, 2008). Among the exotic reef-

fishes newly recorded in the Canary Islands, one species identified by Falcon et al.

(2015; plate 4B) as the (naturally trans-Atlantic) damselfish, Abudefduf taurus (Muller \&

Troschel, 1848), actually is most likely the IWP species $A$. sordidus (Forsskal, 1775)

(GR Allen, pers. comm. 2016). Since A. sordidus is a dull-colored species that is not

found in the aquarium trade (Rhyne et al., 2015), this occurrence represents support for

the hypothesis that IWP reef-fishes are carried from their native ranges into the Atlantic

by petro-platforms. Another example, in the Pacific Ocean, reported by Myers \&

Donaldson (1996) and Myers (1999, p 183), is the damselfish Neopomacentrus

violascens (Bleeker, 1848), which they proposed was transported from the Philippines

to Guam, where it is not native, by a bio-fouled military barge. It has now established a population at Guam, living on bio-fouled mooring chains rather than on natural substrata.

Are there movements to the SwGoMx of petro-platforms from the two areas of the native range of $N$. cyanomos that contain the lineages of that species found in the SwGoMx? The website www.infield.com/rigs (accessed Dec. 20, 2017) provides information on the construction sites of drilling-platforms and drill ships currently located in the offshore oilfields of different countries. A review of information on that site of the origins of such platforms and ships showed that about $60 \%$ of those listed as currently being used in the SwGoMx were constructed at sites within the native ranges of the two lineages found in the SwGoMx. Many drilling rigs currently in use in other offshore oilfields in the tropical Atlantic also were constructed at sites within the native range of 
411 N. cyanomos (Table 2). In some cases rigs were moved from those construction sites

412 directly to the Atlantic oilfield; in other cases, particularly for older rigs, their movements

413 prior to arrival at those offshore fields are unclear. These linkages produced by

414 relocations of drilling-rigs represent only part of a global web of movements of new and

415 used drilling-rigs, drill-ships, support vessels, and parts of production platforms within

416 and between oceans that could result in establishment of exotic sessile and mobile reef

417 organisms well beyond their native ranges (Wanless et al., 2010; Yeo et al., 2010;

418 Pajuelo et al., 2016).

Drilling-rigs are moved long distances either by being towed by tugboats while in the sea (a wet-tow), or by being transported out of the water on the deck of a heavy-lift ship (a dry-tow). Although dry-tows are more commonly used for long-distance and

422 interoceanic relocations of rigs, both dry- and wet-tows have been used to move rigs

423 from the IWP to the GoMx around the southern tip of Africa (e.g. a wet-tow:

424 https://mb50.wordpress.com/tag/cape-of-good-hope/, accessed Dec. 15, 2017); a dry425 tow:

https://www.rigzone.com/news/oil_gas/a/16673/dockwise delivers thunder horse pdq to corpus christi/, accessed Dec. 15, 2017). Wet-towed rigs moved by this route would have the potential to transport marine organisms from the IWP to the GoMx or to any other Atlantic offshore oil-field.

The southern tip of Africa has a temperate environment that very likely inhibits

431 the transport of tropical fish from the Indian Ocean to the Atlantic Ocean. However, 432 summer temperatures at that tip are $\sim 20^{\circ} \mathrm{C}$, similar to winter temperatures at the 433 latitudinal limits of the native geographic range of $N$. cyanomos. In addition, 
434 temperatures there are distinctly warmer during El Niño years (Dufois \& Rouault 2012),

435 and there are periodic leakages of warm water from the southern Indian Ocean around

436 the southern tip of Africa into the South Atlantic (Duncombe Rae, 1991).Thus

437 temperatures suitable for the rig-transport of $N$. cyanomos are intermittently available off 438 that tip.

Whether any of the rigs employed in the GoMx arrived there from the IWP via the

Suez Canal is unclear. Limitations in the capacity of that canal may oblige some rigs to

move between the Mediterranean and IWP via southern Africa (e.g.

https://www.offshoreenergytoday.com/fairstar-to-transport-ensco-105-jack-up-rig-from-

443 malta-to-singapore/, accessed Dec 15, 2017)). However, rigs have been wet-towed

444 from the Persian Gulf to northern Europe via the Suez canal (e.g.

445 https://www.rigzone.com/news/oil gas/a/60320/aker solutions aker h6e sets sail for

446 norway $/$, accessed Dec 15,2017$)$. Sea temperatures are at or above $20^{\circ} \mathrm{C}$ for $6-8$

447 months each year in the southern Mediterranean, which would facilitate transport of

448 tropical organisms on rigs passing through. However, the only connections between the

449 IWP and tropical Atlantic oilfields that we were able to find through web searches

450 involved relocations of rigs around southern Africa.

The genetic structure of the SwGoMx population of N. cyanomos indicates it was

453 through a genetic bottleneck during the expansion of their populations from a small

454 group of founders in that area. These results support the hypothesis that a large number

455 of fish were transported to that area, which would be most consistent with the

456 movement of one or more petro-platforms from the native range. Neopomacentrus 
457 cyanomos appears to be the first known tropical reef-fish to have successfully

458 established outside its native geographic range, in another ocean, as a result of

459 transport by a petro-platform.

460 How many introductions of $N$. cyanomos to the GoMx?

The fact that the SwGoMx population of $N$. cyanomos is derived from two

462 lineages mostly confined to different oceans raises the question of whether that

population was derived from two well-separated sources and two separate

464 introductions. While those lineages are largely allopatric, both are present at Gujarat, in

northwestern India (Fig. 2). That occurrence and the absence of the Pacific lineage

(group 4; Fig. 2) at Sri Lanka (in an admittedly small sample of fish), which is closer to

467 the Pacific than is Gujarat, suggests that the presence of group 4 at western India may

not be natural. Is there evidence that offshore oil-industry activity provides connections

469 that could have carried group 4 fish from the Pacific to Gujarat?

470

There is a major, active offshore-petroleum area immediately to the south of the

broad Kathiawar peninsula of Gujarat that projects well into the Indian Ocean (e.g.

472 https://watchers.news/data/uploads/2012/04/Untitled1.png, accessed Sept. 15, 2017).

473 Of 41 petro-platforms used in India that are listed by www.infield.com/rigs, (accessed

474 July 15, 2017), 15 were constructed in Singapore and two in southeast China, near the

475 Taiwan sample of the Group 4 lineage of $N$. cyanomos. Further, there is a major global

476 shipbreaking site on either side of the Gujarat peninsula, one at Gaddani in Pakistan,

$477 \sim 360 \mathrm{~km}$ west of Gujarat, the other at Alang, at the eastern base of that peninsula, in

478 India. A list of decommissioned vessels of various types that were sent to those two 
479 sites during 2015-2016 (provided by www.shipbreakingplatform.org) shows that 480 decommissioned offshore platforms and support vessels do get taken from various 481 locations within the northwest Pacific (Indonesia, Singapore, Vietnam, south-east 482 China) to both those shipbreaking yards. In addition, other types of decommissioned 483 vessels also make similar last voyages. Decommissioned vessels transiting to a shipbreaker do not have clean hulls; rather, typically they are heavily bio-fouled (Davidson et al., 2008), which would facilitate long-distance transport of fishes such as N. cyanomos.

Thus, there are interoceanic connections involving movements of drillingplatforms, drill-ships, offshore support vessels, and decommissioned vessels of various types that could be responsible for the occurrence of both lineages in the sample from Gujarat. The existence of such connections supports the hypothesis that the occurrence of $N$. cyanomos in the GoMx could well be due to a single introduction (the simplest explanation) rather than multiple introductions from different source locations.

\section{When and where in the GoMx was $N$. cyanomos initially introduced?}

Neopomacentrus cyanomos was first recorded at Coatzacoalcos, in the southwest corner of the GoMx in July 2013 by González-Gándara \& de la CruzFrancisco (2014), who thought it had been introduced directly to that port from its native range. However, several years later, inspection of underwater photographs taken in July 2013 at Cayo Arcas reef, $350 \mathrm{~km}$ northwest of Coatzacoalcos, showed that it was present in significant numbers at both those sites at the same time in 2013 (Robertson et al., 2016 a). Furthermore, this species was recorded in appreciable numbers on reefs 
501 near Veracruz, $200 \mathrm{~km}$ northwest from Coatzacoalcos and $450 \mathrm{~km}$ west from Cayo

502 Arcas, in October 2014 (Robertson et al., 2016 b). These observations indicate that $N$.

503 cyanomos was already well established over a large area in the SwGoMx when it was

504 first discovered, and indicate that its arrival in that area occurred long before 2013. More

505 recently, $N$. cyanomos has been found to be even more widely spread across the

506 SwGoMx (Schofield, 2017, accessed Dec. 20, 2017). Between 2016 and 2017, this

507 species also was found at widely separated sites in the northern GoMx: on a natural

508 reef off Texas in the west, on a petro-platform off Louisiana, and on an artificial reef off

509 the Florida Panhandle in the east (Schofield, 2017, accessed Dec. 20, 2017).

The occurrence of $N$. cyanomos at two widely separated sites at the time it was

first discovered in the SwGoMx demonstrates that the location at which any alien

512 species is first discovered should not be equated with the site at which it was first

513 introduced. This issue is particularly applicable to $N$. cyanomos, since it is small, dully

514 colored, and readily mistaken for a native planktivorous damselfish, the brown chromis,

515 Chromis multilineata (Guichenot, 1853), which it resembles in size, shape, and

516 coloration. Distinguishing small juveniles of these two species in the field is more

517 difficult than distinguishing adults. The brown chromis is particularly abundant on coral

518 reefs in the SwGoMx, where it is far more numerous than N. cyanomos (DRR personal

519 observations), and also lives on petro-platforms in the north and south of the GoMx. In

520 that area both species often co-occur in feeding aggregations that are predominantly

521 composed of brown chromis. Small numbers of N. cyanomos sharing a reef (or petro-

522 platform) with many brown chromis could easily be ignored or mistaken for that species

523 by a diver who is not familiar with, and not actively searching for $N$. cyanomos. 
Given the difficulty in detecting the timing of the arrival of $N$. cyanomos in the

525 SwGoMx, the possibility that it was initially introduced to the northern GoMx rather than

526 the southwest part cannot be ruled out at present. Drilling-platforms originated from

527 sites in the native geographic ranges of both lineages of $N$. cyanomos occur in both the

528 northern and southern GoMx (Table 2). The fact that $N$. cyanomos seems to be much

529 more common in the SwGoMx, even superabundant on petro-platforms there, and that

530 it was first detected there, does suggest that it was initially introduced there. However,

531 the greater abundance of this species in the SwGoMx may simply be due to more

532 favourable environmental conditions (warmer water and greater availability of coral

533 reefs), rather than prior occurrence there.

\section{Future directions for research}

Three sets of DNA barcode data from N. cyanomos at several sites in its native

range should help clarify some of the questions concerning the origins of the SwGoMx population. First, as can be seen from the numbers of platforms dispatched to other countries from Singapore (www.infield.com/rigs), that city-state is a major global player in the business, has produced the largest number of GoMx petro-platforms that originated in the IWP, and is a site for servicing of used platforms coming from various areas, including the tropical Atlantic. Documenting which lineage(s) of $N$. cyanomos occur in Singapore would help evaluate the potential for Singapore as a source

543 population for the Gulf of Mexico population of this damselfish. Second, a substantial 544 set of DNA-sequence data also is needed from Gujarat, to indicate the proportional 545 abundances of groups 1 and 4 lineages in the population there, and to show whether 546 group 4 haplotypes present there are shared with west Pacific sites. Third, DNA 
547 barcode data from confirmed $N$. cyanomos from the Philippines would clarify the extent

548 to which $N$. cyanomos is actually involved in the aquarium trade to the Americas, and

549 whether Philippine fish belong to a DNA lineage found in the GoMx.

550 A host of other questions raised by the appearance of N. cyanomos in the GoMx

551 deserve attention in future research. Prime examples include: (i) Where in the GoMx

552 was N. cyanomos initially introduced: the northern or southern parts of that Gulf? (ii)

553 Does N. cyanomos represent a true invasive species that will have negative effects on

554 reef ecosystems of the Greater Caribbean, or a relatively innocuous addition to the reef-

555 fish fauna of that region (cf. Davis et al., 2011)? (iii) What factors contribute to the

556 evident success of this species in the Gulf of Mexico, on both petro-platforms and coral

557 reefs? (iv) Why is $N$. cyanomos the only known successful alien reef-fish that appears to

558 have arrived in the GoMx via relocated petro-platforms? Is that a reflection of the low

559 frequency of wet-tows of rigs via southern Africa during intermittent warm-water

560 episodes; or did other species arrive in numbers in the GoMx but fail to establish (cf.

561 Oda \& Parrish, 1981), or are there other alien fish species present there that have yet to

562 be noticed (e.g. small, crevice-living, cryptic species)? (v) Has N. cyanomos, (or other

563 IWP reef-fishes) established any unnoticed population(s) on platforms in offshore oil

564 fields in other tropical parts of the Atlantic Ocean, such as western Africa and Brazil,

565 which might have acted as stepping stones that helped this species spread into the

566 GoMx on platforms or support vessels moved between Atlantic oil fields?

\section{CONCLUSIONS}

Various lines of evidence support the petro-platform translocation hypothesis: 
570 tropical reef-fish; $N$. cyanomos can live in a dense population on a petro-platform; petro-

571 platforms are regularly constructed within the parts of the native range of $N$. cyanomos

572 where the SwGoMx lineages occur, and transported from there to the SwGoMx;

573 translocated platforms has been implicated as vectors of long-distance transport of

574 tropical reef-fishes, sometimes in sufficient numbers to allow them to establish breeding

575 populations in non-native areas; members of the genus Neopomacentrus apparently

576 can be transported long distances by bio-fouled structures in sufficient numbers to

577 establish populations outside their native ranges; and, finally, the genetic diversity of the

578 SwGoMx population of $N$. cyanomos indicates it is derived from a large and genetically

579 diverse population of founders, consistent with large numbers of fish being transported

580 by a drilling-platform. Neopomacentrus cyanomos has characteristics well suited to

581 being transported by a petro-platform in sufficient numbers to establish a population far

582 from its native geographic range: it is small (maximum length $\sim 12 \mathrm{~cm}$ ), can feed on the

583 plankton stream produced by a slow-moving platform (1-6 kts (2-11 kph); Yeo et al.,

584 2010), and can live in high-density aggregations on small amounts of relatively low-

585 profile, bio-fouling cover.

586

Heavy-lift ships, which carry offshore drilling-rigs on the deck, out of the water,

587

588

589

590

591

592

often are employed for long-distance relocation of rigs. The use of this existing technology for all long-distance transport of such rigs would greatly reduce the risk of any types of marine organisms being transported outside their native ranges by relocated rigs. Such transport should be used not only for movements of rigs between oceans such as the Indo-Pacific and Atlantic, or the Mediterranean and Atlantic, but also relocations between regions with different biotas in the same ocean, such as those 
593 implicated in alien-fish transfers between the eastern and western tropical Atlantic.

\section{ACKNOWLEDGEMENTS}

595

596

597

598

599

600

601

602

603

604

605

606

607

608

609

610

611

612

613

614

Tissue samples, sequences, and/or data for comparison were graciously provided by Gerald Allen and Mark Erdmann (Indonesia), Gavin Gouws, Roger Bills, and Phillip Heemstra (SW Indian Ocean), Luiz Rocha and Joseph Battista (Djibouti, Somaliland, and Saudi Arabia), Mark McGrouther and Jeff Leis (Australia), Nicolas Hubert (Madagascar), Dirk Steinke and Glenn Moore (Australia), Allan Connell (Mozambique), Fenton Walsh and Tim Bennett (Australia), Dhaval Bamaniya (India), Chiahao Chang and Kwang-Tsao Shao (Taiwan), Alyssa Marshell and Mark Priest (Oman), as well as Christopher Buerner and Adam Mangino of Quality Marine, Los Angeles, and Jason Edward of Greenwich Aquaria for aquarium trade specimens.

Nicola Mulinaris of www.shipbreakingplatform.org supplied a list of petro-platforms, drillships and offshore support vessels sent to different shipbreaking sites during 2015-16.

We thank Quetzalli Hernandez for help collecting specimens in the Gulf of Mexico, Rosa Gabriela Beltran López for support with the genetic analyses, and Maribel Badillo for photographs of the $N$. cyanomos specimens collected at Madagascar Reef. Giacomo Bernardi, Victor Seixas and Luis Malpica Cruz made useful comments of the ms.

\section{REFERENCES}

Ajemian MJ, Wetza JJ, Shipley-Lozano B, Stunz GW. 2015. Rapid assessment of fish communities on submerged oil and gas platform reefs using remotely operated vehicles. Fisheries Research 167: 143-155.

doi.org/10.1016/j.fishres.2015.02.011. 
615 Allen GR. 1991. Damselfishes of the world. Mergus, Melle, Germany, 271 pp.

616 Anderson AB, Salas EM, Rocha LA, Floeter SR, 2017. The recent colonization of south Brazil by the Azores chromis Chromis limbata. Journal of Fish Biology 91: 558-573. doi:10.1111/jfb.13363.

Arndt E, Schembri PJ. 2015. Common traits associated with establishment and spread of Lessepsian fishes in the Mediterranean Sea. Marine Biology 162: 2141-2153.

Bandelt H, Forster P, Röhl A. 2000. Median-joining networks for inferring intraspecific phylogenies. Molecular Biology and Evolution 16:37-48.

Bax N, Williamson A, Aguero M, Gonzalez E, Geeves W. 2003. Marine invasive species: a threat to global biodiversity. Marine Policy. 27: 313-323.

Bernardi G, Golani D, Azzurro E. 2010. The genetics of Lessepsian bioinvasions. In: Golani D, Appelbaum-Golani B, eds. Fish invasions of the Mediterranean Sea: change and renewal. Sofia, 71-84.

Claisse JT, Pondella DJ, Love M, Zahn LA, Williams CM, Williams JP, Bull AS. 2014. Oil platforms off California are among the most productive marine fish habitats globally. PNAS 11; 15462-15467. https://doi.org/10.1073/pnas.1411477111

Cohen AN. 2006. Species introductions and the Panama Canal. In: Gollasch S, Galil BS, Cohen AN, eds. Bridging Divides: Maritime Canals as Invasion Corridors. Springer, 127-206.

Coleman RR, Gaither MR, Kimoko B, Stanton FG, Bowen BW, Toonen RJ. 2014. Large-scale introduction of the Indo-Pacific damselfish Abudefduf vaigiensis into 
637

638

639

640

641

642

643

644

645

646

647

648

649

650

651

652

653

654

655

656

657

658

Hawai'i promotes genetic swamping of the endemic congener $A$. abdominalis. Molecular Ecology 23: 5552-5565.

Consoli P, Romeo T, Ferraro M, Sara G, Andaloro F. 2013. Factors affecting fish assemblages associated with gas platforms in the Mediterranean Sea. Journal of Sea Research 77: 45-52.

Coutts ADM, Dodgshun TJ. 2007. The nature and extent of organisms in vessel seachests: A protected mechanism for marine bioinvasions. Marine Pollution Bulletin 54: $875-886$.

Davidson IC, McCann LD, Fofonoff PW, Sytsma MD, Ruiz GM. 2008. The potential for hull-mediated species transfers by obsolete ships on their final voyages. Diversity and Distributions 14: 518-529. DOI: 10.1111/j.1472-4642.2008.00465.x

Davis MA, Chew MK, Hobbs RJ, Lugo AE, Ewel JJ, Vermeij GJ, Brown JH, Rosenzweig ML, Gardener MR, Carroll SP, Thompson K, Pickett STA, Stromberg JC, Del Tredici P, Suding KN, Ehrenfeld JG, Grime JP, Mascaro J, Briggs JC. 2011. Don't judge species on their origins. Nature 427: 153-154.

Dufois F, Rouault M. 2012. Sea surface temperature in False Bay (South Africa): towards a better understanding of its seasonal and inter-annual variability. Continental Shelf Research 43: 24-35

Dulcic J, Dragicevic B. 2013. Paranthias furcifer (Perciformes, Serranidae), a new alien fish in the Mediterranean Sea. Journal of Fish Biology 82: 332-337.

Duncombe Rae CM, 1991. Agulhas retroflection rings in the South Atlantic Ocean: an overview. South African Journal of Marine Science 11: 327-344. 
659 Falcon JM, Herrera H, Ayza O, Brito A. 2015. New species of tropical littoral fish 660 found in Canarian waters. Oil platforms as a central introduction vector. Revista Academia Canaria de Ciencias 27: 67-82.

662

663

664

665

666

667

668

669

670

671

672

673

674

675

676

677

678

679

680
Ferreira CEL, Gonçalves JEA, Coutinho R. 2006. Ship hulls and oil platforms as potential vectors to marine species introduction. Journal of Coastal Research, SI 39 (Proceedings of the 8th International Coastal Symposium), 1341 - 1346.

Foster BA, Willan RC. 1979. Foreign barnacles transported to New Zealand on an oil platform. New Zealand Journal of Marine and Freshwater Research 13: 143-149.

Friedlander AM, Ballesteros E, Fay M, Sala E. 2015. Marine communities on oil platforms in Gabon, West Africa: high biodiversity oases in a low biodiversity environment PLoS ONE, doi:10.1371/journal.pone.0103709.

Fu YX, Li WH. 1993. Statistical test of neutrality of mutations. Genetics 133:693-709.

Galil BS. 2008. Alien species in the Mediterranean Sea - which, when, where, why? Hydrobiologia 606: 105-116.

González-Gándara C, de la Cruz-Francisco V. 2014. Unusual record of the IndoPacific pomacentrid Neopomacentrus cyanomos (Bleeker, 1856) on coral reefs of the Gulf of Mexico. Biolnvasions Records 3: 49-52.

Harpending HC, Sherry S, Rogers A, Stoneking M. 1993. The genetic structure of ancient human populations. Current Anthropology. 34: 483-496.

Hastings RW, Ogren LH, Mabry MT. 1976. Observations on the fish fauna associated with offshore platforms in the northeastern Gulf of Mexico. US Fishery Bulletin 74: $387-402$. 
681 Hopkins GA, Forrest BM. 2010. Challenges associated with pre-border management

682

683

684

685

686

687

688

689

690

691

692

693

694

695

696

697

698

699

700

701

702

703 of biofouling on oil rigs. Marine Pollution Bulletin 60: 1924-1929.

Ivanova NV, Zemlak TS, Hanner RH, Hebert PDN. 2007. Universal primer cocktails for fish DNA barcoding. Molecular Ecology Notes 7: 544-548.

Lango Reynoso F, Castañeda-Chavez M, Zamora-Castro JE, Hernández-Zárate G, Ramirez-Barragán MA, Solis-Morán E. 2012. La acuariofilia de especies ornamentals marinas: un mercado de retos y oportunidades. Latin American Journal of Aquatic Research 40: 12-21.

Librado P, Rozas J. 2009. DnaSP v5: A software for comprehensive analysis of DNA polymorphism data. Bioinformatics 25: 1451-1452.

Martin CJB, Lowe CG. 2010. Assemblage structure of fish at offshore petroleum platforms on the San Pedro shelf of southern California. Marine and Coastal Fisheries: Dynamics, Management, and Ecosystem Science 2: 180-194. https://doi.org/10.1577/C09\&ndash;037.1

Mineur F, Cook EJ, Minchin D, Bohn K, Macleod A, Maggs CA. 2012. Changing coasts: Marine Aliens and artificial structures. Oceanography and Marine Biology: An Annual Review, 50: 189-234.

Mousset S, Derome N, Veuille M. 2004. A test of neutrality and constant population size based on the mismatchdistribution. Molecular Biology and Evolution. 21: 724-731.

Muirhead JR, Minton MS, Miller WA \& Ruiz GM. 2015. Projected effects of the Panama Canal expansion on shipping traffic and biological invasions. Diversity and Distributions 21: 75-87. 
704 Myers RF. 1999. Micronesian Reef Fishes. Coral Graphics, Guam, 430 pp.

705 Myers RF, Donaldson TJ. 1996. Note: new and recent records of fishes from the

706

707

708

709

710

711

712

713

714

715

716

717

718

719

720

721

722

723

724

725

726 Mariana Islands. Micronesica 28: 207-266.

Occhipinti-Ambrogi A, Marchini A, Castelli GCA, Chimenz C, Cormaci M, Froglia C, Furnari G, Gambi MC, Giaccone G, Giangrande A, Gravili C, Mastrototaro F, Mazziotti C, Orsi-Relini L, Piraino S. 2011. Alien species along the Italian coasts: an overview. Biological Invasions 13: 215-237.

Oda DK \& Parrish JD. 1981. Ecology of commercial snappers and groupers introduced to Hawaiian reefs. Proceedings of the Fourth International Coral Reef Symposium, Manila I: 59-67.

Pajuelo JG, González JA, Triay-Portella R, Martin JA, Ruiz-Díaz R, Lorenzo JM, Luque A. 2016. Introduction of non-native marine fish species to the Canary Islands waters through oil platforms as vectors. Journal of Marine Systems 163: 23-30. doi.org/10.1016/j.jmarsys.2016.06.008.

Posada, D. 2008. J model test: phylogenetic model averaging. Molecular Biology and Evolution 25: 1253-1256.

Pradella N, Fowler AM, Booth DJ, Macreadie PI. 2014. Fish assemblages associated with oil industry structures on the continental shelf of northwestern Australia. Journal of Fish Biology 84: 247-255.

Ramos-Onsins SE, Rozas J. 2002. Statistical properties of new neutrality tests against population growth. Molecular Biology and Evolution 19: 2092-2100.

Ratnasingham S, Hebert PDN. 2007. BOLD: The Barcode of Life Data System (www.barcodinglife.org). Molecular Ecology Notes 7: 355-364. 
727 Rhyne AL, Tlusty MF, Holmberg RJ, Szczebak J. 2015.

$728 \quad$ www.aquarium.tradedata.org (accessed September 30, 2015)

729

730

731

732

733

734

735

736

737

738

739

740

741

742

743

744

745

746

747

Robertson DR, Allen GR. 2015. Shorefishes of the tropical Eastern Pacific: online information system. Version 2.0. Smithsonian Tropical Research Institute, Balboa, Panama. http://biogeodb.stri.si.edu/sftep/en/pages

Robertson DR, Perez-España H, Nuñez Lara E, Puc Itza F, Simoes N. 2016 a. The fishes of Cayo Arcas (Campeche Bank, Gulf of Mexico): an updated checklist. Zookeys 640: 139-155. DOI: 10.3897/zookeys.640.10862.

Robertson DR, Simoes N, Gutiérrez Rodríguez C, Piñeros VJ, Perez-España H. 2016 b. An Indo-Pacific damselfish widely established in the southwest Gulf of Mexico: prospects for a wider, adverse invasion. Journal of the Ocean Science Foundation 19: 1-17, DOI: 10.5281/zenodo.44898.

Robertson DR, Van Tassell JVT. 2015. Shorefishes of the Greater Caribbean: online information system. Version 1.0. Smithsonian Tropical Research Institute, Balboa, Panama. http://biogeodb.stri.si.edu/caribbean/en/pages

Schofield PJ. 2017. Neopomacentrus cyanomos (Bleeker, 1856) Factsheet. U.S. Geological Survey, Nonindigenous Aquatic Species Database, Gainesville, FL. http://nas.er.usgs.gov/queries/FactSheet.aspx?SpeciesID=2936. accessed October 10, 2017.

Schofield PJ, Morris JA, Jr, Akins L. 2009. Field guide to nonindigenous marine fishes of Florida. NOAA Technical Memorandum NOS NCCOS 92: 1-133. 
748 Semmens BX, Buhle ER, Salomon AK, Pattengill-Semmens CV. 2004. A hotspot of

749 non-native marine fishes: evidence for the aquarium trade as an invasion

750 pathway. Marine Ecology Progress Series 266: 239-244.

751 Seixas VC, Zanol J, Magalhães WF, Paiva PC. 2017. Genetic diversity of Timarete

752

753

754

755

756

757

758

759

760

761

762

763

764

765

766

767

768

769

770 punctata (Annelida: Cirratulidae): Detection of pseudo-cryptic species and a potential biological invader. Estuarine, Coastal and Shelf Science 197: 214-220.

Silvestro D, Michalak I. 2012. raxmIGUI: a graphical front-end for RAxML. Organisms Diversity and Evolution 12: 335-337.

Simoes N, Robertson DR. 2016. An Indo-Pacific damselfish on an oil-platform in the southwest Gulf of Mexico. Zenodo .doi: 10.5281/zenodo.5845.

Slatkin M, Hudson RR. 1991. Pairwise comparisons of mitochondrial DNA sequences in stable and exponentially growing populations. Genetics 129:555-562.

Stamatakis A. 2006. RAxML-VI-HPC: maximum likelihood-based phylogenetic analyses with thousands of taxa and mixed models. Bioinformatics 22: 26882690.

Tajima T. 1989. Statistical method for testing the neutral mutation hypothesis by DNA polymorphism. Genetics 123: 585-595.

Tamura K. Stecher G. Peterson D. Filipski A. \& Kumar S. 2013. MEGA6: molecular evolutionary genetics analysis version 6.0. Molecular Biology and Evolution, 12: $2725-2729$.

Tavaré S. 1986. Some probabilistic and statistical problems in the analysis of DNA sequences. Lectures on mathematics in the life sciences 17: 57-86. 
771 Topolski MK, Szedlmayer ST. 2004. Vertical distribution, size structure, and habitat

772

773

774

775

776

777

778

779

780

781

782

783

784

785

786

787

788

789

790

791

792 associations of four Blenniidae species on gas platforms in the northcentral Gulf of Mexico. Environmental Biology of Fishes 70: 193-201.

Torquato F, Jensen HM, Range P, Bach SS, Ben-Hamadou R, Sigsgaard EE, Thomsen PF, Møller PR, Riera R. 2017. Vertical zonation and functional diversity of fish assemblages revealed by ROV videos at oil platforms in The Gulf. Journal of Fish Biology. doi: 10.1111/jfb.13394.

Tsadok R, Rubin-Blum M, Shemesh E, Tchernov D. 2015.. On the occurrence and identification of Abudefduf saxatilis (Linnaeus, 1758) in the easternmost Mediterranean Sea. Aquatic Invasions 10: 101-105.

Wanless RM, Scott S, Sauer WHH, Andrew TG, Glass JP, Godfrey B, Griffiths C, Yeld E. 2010. Semi-submersible rigs: a vector transporting entire marine communities around the world. Biological Invasions 12:2573-2583.

Ward RD, Hanner R, Hebert PDN. 2009. The campaign to DNA barcode all fishes, FISHBOL. Journal of Fish Biology, 74, 329-356.

Ward RD, Zemlak TS, Innes BH, Last PR, Hebert PDN. 2005. DNA barcoding Australia's fish species. Philosophical Transactions of the Royal Society B: Biological Sciences, 360: 1847-1857.

Wilcox CL, Motomura H, Matsunuma M, Bowen BW. 2017. Phylogeography of lionfishes (Pterois) indicate taxonomic over splitting and hybrid origin of the invasive Pterois volitans. Journal of Heredity, 2016: 1014, doi:10.1093/jhered/esx056 
793 Wonham MJ, Carlton JT, Ruiz GM. 2000. Fish and ships: relating dispersal frequency

794 to success in biological invasion. Marine Biology 136: 1111-1121.

795 Yeo DCJ, Ahyong ST, Lodge DM, Ng PKL, Naruse T, Lane DJW. 2010.

796 Semisubmersible oil platforms: understudied and potentially major vectors of

797 biofouling-mediated invasions. Biofouling 26: 179-186. 


\section{Figure 1}

Haplotype network

Haplotype network of N. cyanomos from its native range and the southwest Gulf of Mexico, and of aquarium-trade "N. cyanomos" (=N. taeniurus) from the Philippines. Number of mutational steps: each red line indicates a single step, boxed number indicates number of multiple steps. Each multicolored haplotype pie indicates the abundance of a haplotype found at multiple locations. 


\begin{tabular}{l} 
Hypothetical haplotypes \\
\hline Gulf of Mexico \\
\hline Taiwan \\
West Papua (Indonesia) \\
Flores (Indonesia) \\
Papua New Guinea \\
eastern Australia \\
Solomon Islands \\
\hline Western Australia \\
\hline Oman \\
Gujarat (India) \\
Sri Lanka \\
Saudi Arabia \\
Djibouti \\
Somaliland \\
\hline Seychelles \\
Madagascar \\
Mozambique
\end{tabular}

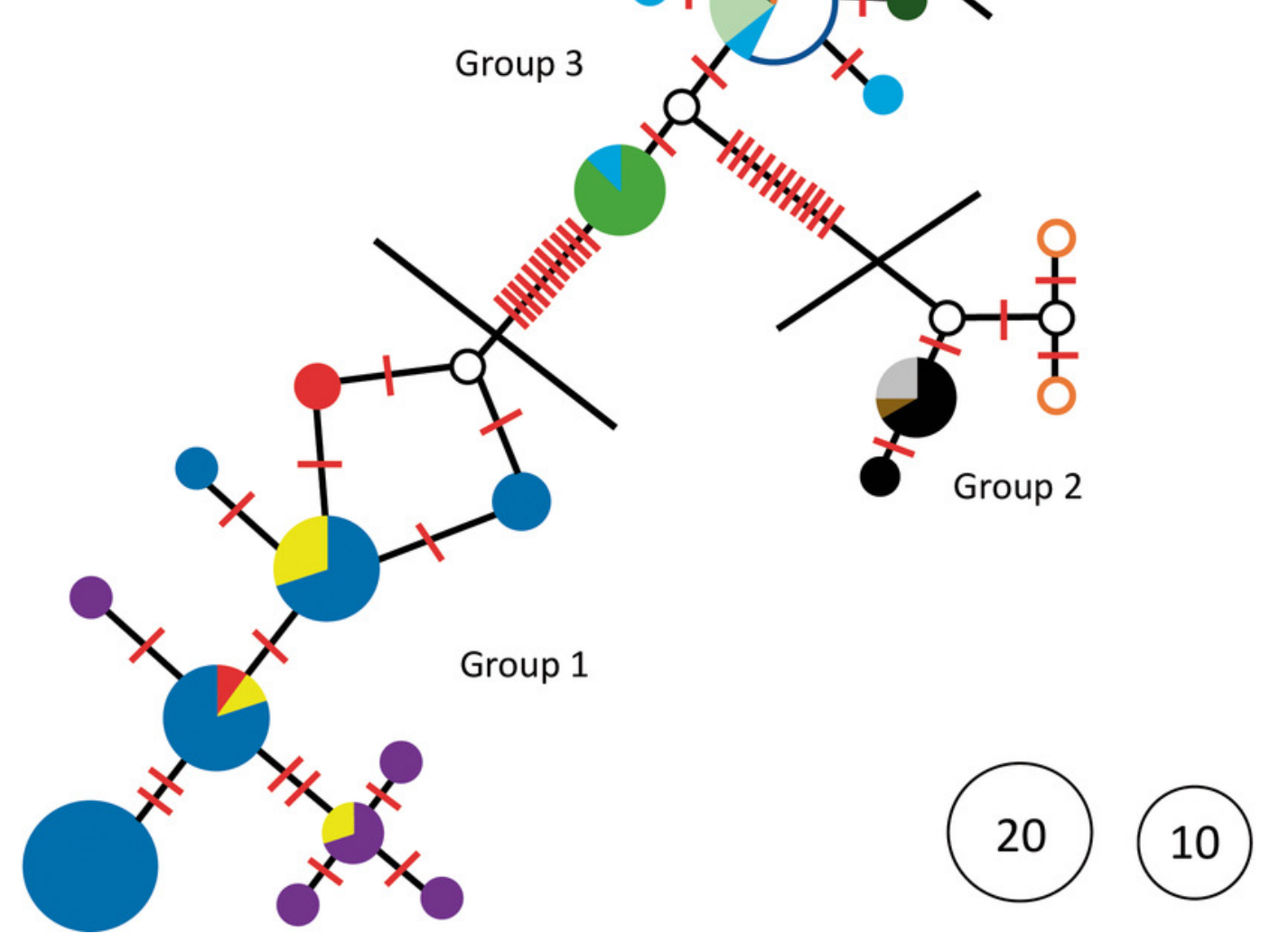




\section{Figure 2}

Locations of sites with different haplotype groups

Locations of sites within the Indo-west Pacific and the southwest Gulf of Mexico from which individuals were obtained from four different haplotype groups (see Figure 1) of $N$. cyanomos, and of aquarium-trade "N. cyanomos" (=N. taeniurus) from the Philippines. The ML (bootstrap support $>85 \%$ in all cases) tree is shown as an inset. The color scheme illustrates the geographic distributions of the four major genetic lineages of N.cyanomos.

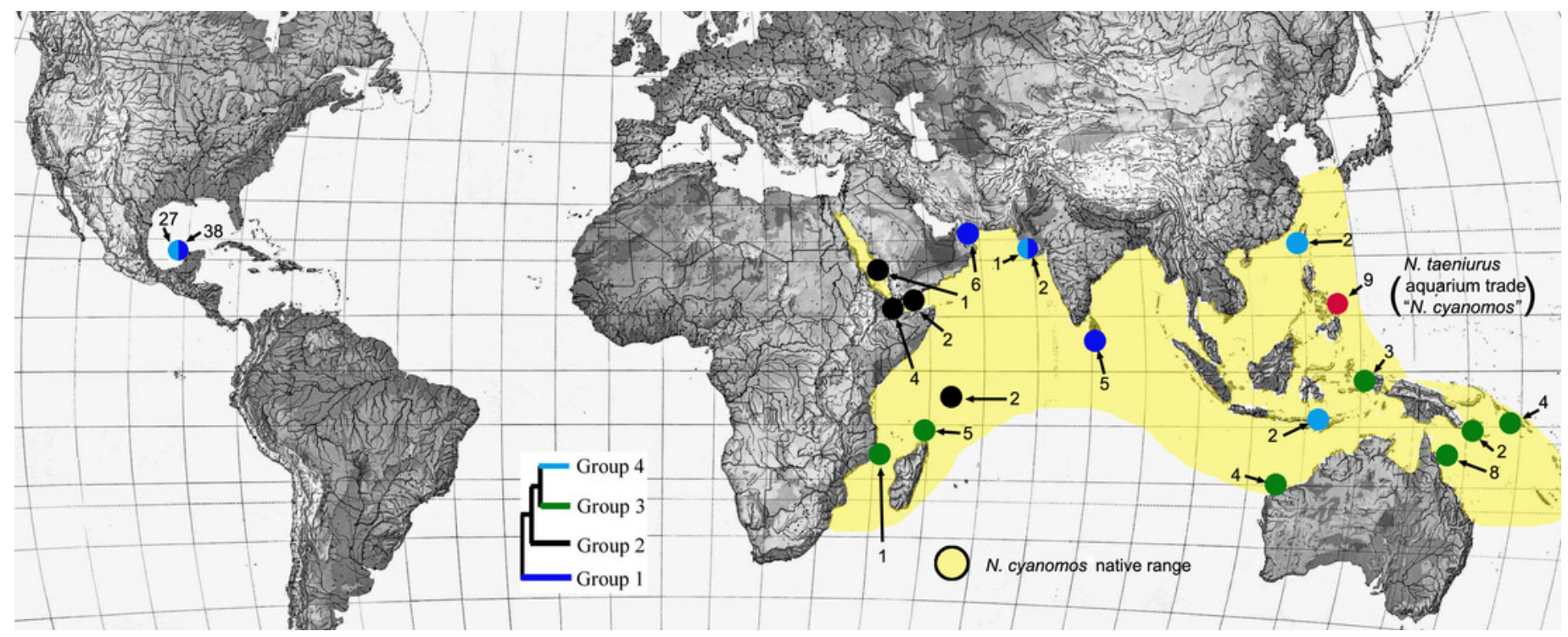




\section{Table $\mathbf{1}$ (on next page)}

Genetic diversity parameters for different genetic groups of $N$. cyanomos from both the native Indo-West Pacific range and the Gulf of Mexico. 


\begin{tabular}{lllllllllll}
1 & Genetic group & $\mathbf{N}$ & $\mathbf{S}$ & $\mathbf{H}$ & $\mathbf{T}$ & $\mathbf{h}$ & $\mathbf{D}$ & $\mathbf{F s}$ & $\mathbf{R}_{\mathbf{2}}$ & $\mathbf{r}$ \\
\hline 2 & Group 1 native & 13 & 8 & 8 & 0.0039 & 0.910 & -0.40 & -3.11 & 0.11 & 0.06 \\
4 & Group 2 native & 9 & 5 & 4 & 0.0024 & 0.583 & -0.91 & -0.29 & 0.12 & 0.25 \\
5 & Group 3 native & 29 & 8 & 7 & 0.0027 & 0.700 & -0.66 & -1.22 & 0.09 & 0.19 \\
6 & Group 4 native & 5 & 4 & 4 & 0.0030 & 0.900 & -0.41 & -1.20 & 0.21 & 0.13 \\
7 & All native & 54 & 43 & 23 & 0.0173 & 0.922 & --- & --- & --- & --- \\
8 & Group 1 GoMx & 38 & 5 & 5 & 0.0028 & 0.683 & -1.00 & 1.05 & 0.08 & 0.16 \\
9 & Group 4 GoMx & 26 & 7 & 6 & 0.0020 & 0.603 & -1.08 & -1.93 & 0.08 & 0.06 \\
10 & All GoMx & 65 & 27 & 11 & 0.0183 & 0.823 & --- & --- & --- & --- \\
11 & All native + GoMx & 121 & 49 & 30 & 0.0195 & 0.919 & --- & --- & --- & --- \\
12 & Group 1 native + GoMx & 51 & 12 & 11 & 0.0036 & 0.791 & -0.57 & -2.39 & 0.08 & 0.04 \\
13 & Group 4 native + GoMx & 32 & 8 & 8 & 0.0022 & 0.635 & -1.02 & -2.70 & 0.08 & 0.05 \\
14 & Notes.
\end{tabular}

15 Notes.

$\mathrm{N}=$ sample size; $\mathrm{S}=$ no. polymorphic sites; $\mathrm{H}=$ no. haplotypes; $\pi=$ nucleotide diversity; $h=$ haplotype diversity; $\mathrm{D}=$ Tajima's D; Fs = Fu's Fs statistic [all values of $D$ and Fs were non-significant at $p>0.05$ ]; $R_{2}=$ Ramos-Onsins \& Rozas' $R_{2}$ statistic, $r=$ Harpending's raggedness index [all values of $R_{2}$ and $r$ were nonsignificant at $p>0.05]$. Native $=$ Indo-West Pacific native range; GoMx $=$ Gulf of Mexico 


\section{Table 2 (on next page)}

Indo-West Pacific sources of drilling-rigs present in late 2017 on offshore oilfields of the tropical Atlantic Ocean. 
1

2

3

4

5

6 Brazil

7

8

10

11

12

Notes.

Construction site

\begin{tabular}{|c|c|c|c|c|c|c|c|c|}
\hline $\begin{array}{l}\text { Atlantic } \\
\text { Oilfields }\end{array}$ & $\begin{array}{l}\text { No. } \\
\text { rigs }\end{array}$ & $\begin{array}{l}\text { Persian } \\
\text { Gulf }\end{array}$ & Malaysia & Singapore & China & Taiwan & $\begin{array}{l}\text { South } \\
\text { Korea }\end{array}$ & Japan \\
\hline Brazil & 13 & Yes & - & Yes & Yes & - & Yes & - \\
\hline Colombia & 1 & Yes & - & - & - & - & - & - \\
\hline Mexico & 30 & Yes & - & Yes & Yes & Yes & Yes & Yes \\
\hline Trinidad & 1 & - & - & Yes & - & - & - & - \\
\hline USA & 17 & - & - & Yes & Yes & Yes & - & - \\
\hline West Africa & 13 & Yes & Yes & Yes & - & - & - & Yes \\
\hline
\end{tabular}

1. West Africa = Angola, Cameroon, Congo, Ghana, Ivory Coast and Nigeria.

2. Yes indicates rig(s) at an Atlantic site originated from the particular construction site.

3. No. rigs $=$ no. rigs present at an Atlantic site that were constructed at one or more Indo-West Pacific sites.

4. Venezuela is not included because no rigs of Indo-West Pacific origin are currently based there.

5. Source: http://www.infield.com/rigs/, accessed December 20, 2017. Data from this website only cover currently present rigs, and do not include rigs no longer at a site; e.g. the semi-submersible drilling-rig Deepwater Horizon, which exploded and sank off Louisiana in 2010, is not included among the list of rigs for the US section of the Gulf of Mexico. 